\title{
Reformation af grundtvigianismen
}

\author{
af Viggo Mortensen
}

Vartovbogen. Red. af Asta Paulsen, Jørgen Kristensen og E. Jakob Petersen, 120 s. kr. 40,25. Udg. af Kirkeligt Samfund.

Kirkeligt Samfund vil være et forum for alsidig oplysning og åben debat. Det årlige skrift, Vartovbogen, som man udsender, tjener dette formål på smukkeste vis. Det gælder også 1982udgaven. Sand oplysning får man bl.a. i indledningsartiklen af den nye professor i Det nye Testamentes eksegese i København, Mogens Müller. Hvad skal vi med Bibelen, spørger han, og svarer i grundtvigsk ånd, at den skal lægges opslået og læselig på kirkens alter, derfor er det en anfægtelse for ham, at Bibelen mere og mere opfattes som en privat håndbog for religiøst interesserede. For dermed læser vi bibelen uden for dens sammenhæng. "Kun et galt menneske læser i DSB's køreplan uden at sætte dens tal i forbindelse med togdriften ", siger Müller; men så galt bærer vi os undertiden ad med Bibelen. Og metoderne kan det også knibe med. I virvaret af radikale historisk-kritikere og fundamentalister fastholder Müller Bibelen som trosvidnesbyrd.

Bibelen er ikke en historieløs himmelfalden bog. Men de forudgående slægter har heller ikke blot overrakt os den som et oldtidsminde. Nej, de, der gik forud, har på deres måde bekræftet det bibelske vidnesbyrds tale ved at bære os til dåben og ved at opretholde kirken og dens gudstjeneste som dens ramme. Til denne vederhæftigt oplysende artikel slutter sig smukt Finn Jacobis fortællende gennemgang af historierne om Jesu mor, Maria.

"Vidnesbyrd" er også hovedordet i biskop Olav C. Lindegaards ordinationstale, som er gengivet sidst $\mathrm{i}$ bogen, mens sognepræst Helge Baden Nielsen i sin artikel "At de må blive i Kristus" mere beskæftiger sig med vidnesbyrdets formidling ind $i$ en tid med blufærdighed overfor religionen på den ene side og en videnskabeliggørelse af livssynet på den anden. Udvejen af dilemmaet ser Baden Nielsen i en opmærksomhed for den tradi- 
tion, vi står i, igennem hvilken vi får foræret et sprog, et fortællingens og poesiens billedsprog, som fortolker, forklarer og beriger vores erfaringer. $\mathrm{Og}$ med tradition tænkes åbenbart først og fremmest på den grundtvigske, for der er "ingen der bedre og dybere end Grundtvig har forstået, at kristendommen er tilstede som en sådan mytisk-poetisk tydningshorisont $i$ et menneskes liv. " Artiklen repræsenterer således et forsøg på at læse Grundtvig i forlængelse af K.E. Løgstrup ved, med domprovst Ole Jensens ord fra den forudgående artikel, at hente det teoretiske grundlag hos Løgstrup for en reformation af den stivnede grundtvigianisme.

For det er da hovedsynspunktet i Ole Jensens artikel om »K.E. Løgstrup og "det grundtvigske" idag ", at med Løgstrups teologi har vi med en tidssvarende grundtvigsk teologi at gøre. Det hænger for Ole Jensen at se sammen med, at Løgstrup arbejder fænomenologisk, i "mellemlandet " mellem videnskab og teologi, og det er for Ole Jẹnsen at arbejde grundtvigsk og må være baggrunden for idag at hævde et "menneske først ".

Den kritiske brod, der var i Grundtvigs begreb om folkelighed, ser Ole Jensen genoplivet i Løgstrups kritik af eksperterne og den tekniske rationalitet, som den stærkest kommer til udtryk i den posthume essaysamling "System og Symbol" fra 1982. Den grundtvigianisme, der i løbet af forrige århundrede sejrede sig igennem i dansk folkeliv, sejrede sig i virkeligheden til døde, hævder Ole Jensen, fordi den glemte den historisk-poetiske anskuelses kritiske retning.

Hvis man nu under den synsvinkel kigger på de øvrige artikler i Vartovbogen, så må man nok medgive, at den kritiske brod ikke egentlig er den fremherskende. Den er dog tilstede i Ståle Dyrviks artikel om "historien for skolen - eller livet ", hvor det langsigtede mål "historieforskningen for alle" opstilles.

Asta Paulsens medrivende gengivelse af Emily Brontes roman Stormfulde Højder rejser vigtige moralske og æstetiske spørgsmål, som betænksomt overvejes. Og nu vi er ved det æstetiske: Der er en flot to-siders farvegengivelse af Sven Havsteen-Mikkelsens billedhuggerarbejde på Brattalid i Grønland.

Af særlig-interesse for Grundtvig-receptionen vil Kjeld Holms afhandling om "Sind og Ret" være. Han forsøger her ved hjælp af et motiv hos Jakob Knudsen at etablere en samtale mellem de 
to store i dansk 19. århundredes åndsliv: Kierkegaard og Grundtvig; spørgsmålet er nemlig, mener Holm, "om de var helt så uenige, som de selv troede. "Det bliver dog mest til en læsning af Jakob Knudsens romaner med et fra Kierkegaard i Sløks udlægning hentet begrebsapparat.

Også Svend Andersen vil arbejde i mellemlandet mellem videnskab og teologi, hvad Ole Jensen kalder at arbejde grundtvigsk. Hans artikel om verdensbillede og skabelsestanke har indirekte en kritisk brod mod dem, der vil lade en naturvidenskabelig helhedsopfattelse få patent på virkelighedsbeskrivelse og -tolkning. På baggrund af oplysende videnskabsteoretiske overvejelser til henholdsvis den videnskabelige og teologiske aktivitet tales der imod en indsnævrende kristendomstolkning, hvor teologien kun får med den oplevelige verden at gøre. Med udgangspunkt i K.E. Løgstrups kosmologisk orienterede religionsfilosofiske betragtninger tales der for en dialog mellem teologien og de forskellige naturvidenskabelige discipliner.

Akkurat her kunne Grundtvigs ikke-reducerende videnskabssyn sikkert virke befrugtende ind på de spørgsmål, som må blive nogle af de centrale, hvis det skal komme til den efterlyste reformation af grundtvigianismen. 